\title{
De fem A'er: En evalueringsmodel for læreprocesser på erhvervsuddannelserne
}

(The five A's: An assessment model for vocational education)

\section{Lene Tanggaard}

Aalborg Universitet, Danmark (lenet@hum.aau.dk)

\begin{abstract}
This article develops the contours of a new Five A-model for assessment practices in vocational education. The model develops a combination of the Five A-model taken from creativity research with empirical studies of vocational education. The rationale is to create a basis for description, analysis and development of assessment in vocational education. The Five A-model presents a heuristic method used to describe and reflect on basic assessment practices in vocational education studying the simultaneously related and dynamically interacting role of respectively actors, action, audiences, artefacts and affordances for assessment. On this basis, the article asks not only how research on assessment developed vital distinctions between summative and formative assessment, but also how the idea of formative assessment can be a vehicle to further development of artefacts supporting boundary crossing between schools and learning in the workplace, and furthermore, how apprentices can take responsibility for their own assessment actions. Assessment practices are never neutral, but they contribute in themselves to the valorisation of particular practices, which is why researchers and practitioners in the field must continuously ask critical questions related to the consequences of assessment.
\end{abstract}

Keywords: assessment, dynamic assessment, formative assessment, the five A-model, vocational education 


\section{Indledning}

I denne artikel vil jeg, på basis af 5A-modellen, som vi har udviklet $i$ vores forskningsgruppe (Glăveanu, 2013; Tanggaard \& Glăveanu, 2014), vise, hvordan man kan evaluere læreprocesser blandt eleverne på erhvervsuddannelserne i henhold til de fem dimensioner ( $\mathrm{A}^{\prime}$ er) i modellen. 5A-modellen understreger, at der er mindst 5 dimensioner eller områder, hvor læreprocesser kan vise sig, og hvor vi kan bestræbe os på at evaluere disse læreprocesser. Det gælder:

1. Aktørniveauet. Vi kan undersøge, om eleverne er lærende eller oplever at lære.

2. Aktions- eller handlingsniveauet. Vi kan eksempelvis undersøge, om der er relationer mellem elevernes oplevelser af egen læring og deres handlinger.

3. Audience (tilhørerniveauet). Vi kan undersøge om ideer eller produkter anerkendes som tegn på læring af andre.

4. Artefakter. Vi kan undersøge betydningen af redskaber for udviklingen af læreprocesser. Vil bestemte former for undervisningsteknologier eksempelvis fremme eller hæmme læring? Betyder det eksempelvis noget for læring, om vi arbejder analogt eller digitalt?

5. Affordance. Vi kan undersøge, hvordan materialer, rum og ting kan fremme læring.

De fem dimensioner kan betragtes som en analytisk, heuristisk model, som kan give klarhed over, hvem og hvad og hvordan, der evalueres. Den kan bruges i undervisning såvel som i mere almene sammenhænge, og idet den udstrækker evalueringen til ikke blot at have fokus på individer (elever, lærere, mestre etc.) eller produkter, men også på handlinger, redskaber og kunder vil jeg i artiklen argumentere for, at den kan have særlig relevans i erhvervsuddannelsesregi, hvor evaluering af praktiske færdigheder og håndelag ofte står centralt.

I artiklen udfoldes modellen og herefter gives en række eksempler på evaluering af læreprocesser med afsæt $i$ egne studier på erhvervsuddannelserne.

\section{Evaluering og læreprocesser}

Evalueringsformer er en væsentlig del af reguleringen af det sociale liv på erhvervsuddannelserne. En af de centrale måder, som elever og lærlinge lærer på, er gennem evaluering. Evaluering tjener typisk to formål eller kræver to typer af kompetencer (Boud, 2003). 1) Dels skal man kunne indkredse standarder. Det vil sige, at evaluering indebærer overvejelser over, hvad der i et givet felt tæller som rigtigt og forkert, godt eller mindre godt. Disse standarder vil naturligvis ændre sig over tid i takt med nye krav til opgaveløsningen, ny teknologi og så videre. 
2) Dels skal man være i stand til at foretage disse vurderinger, hvilket ikke altid er det samme som blot at kende og kunne identificere standarderne. Man skal kunne give feedback, kunne guide elever i deres videre læreprocesser og i det hele taget opstille et stillads, der gør det muligt for eleverne at bruge evalueringen fremadrettet. Det er især sidstnævnte dimension af evaluering, der interesserer mig i denne artikel. I det følgende vil jeg derfor, inden 5A-modellen beskrives nærmere, indkredse typer af evaluering, sammenhæng mellem læreprocesser og evaluering og principperne bag formativ, dynamisk evaluering.

Typer af evaluering: Nielsen (2003) har beskrevet, hvordan evaluering er funktionel, når den er med til at ændre forudsætninger for at handle, hvordan evaluering kan være støttende (anerkendelse), rettet mod at forbedre lærlingens deltagelse i praksis (saglige evalueringer) eller følge de måder, som er dominerende i den lokale kultur (evalueringskulturen). Det centrale er, at evalueringspraksis rent faktisk evaluerer de læreprocesser, vi har interesse $i$ at fremme. I en generel definition af evaluering henvises ofte til evaluering som den systematiske opsamling af resultater af en given indsats, der kan have så forskellige mål som kontrol, dokumentation, læring, organisationsudvikling og opsamling af viden (Foss Hansen, 2002). På engelsk vil betegnelsen "evaluation" typisk henvise til evaluering, kontrol og styring af eksempelvis politiske reformer og sociale systemer, mens betegnelsen "assessment" vil henvise til former for test og vurderinger af uddannelses- og læringsindsats (Aastrup Rømer, 2003). I denne artikel vises det, hvordan der i forskellige situationer og praksis 'konstrueres' forskellige former for evaluering, som igen skaber forudsætninger for forskellige måder at lære på. Når jeg i det følgende skriver om praktik og om skole vil jeg med praktik ofte henvise til læreprocesser på en virksomhed, fordi min egen forskning på erhvervsuddannelserne, som jeg refererer til i nærværende artikel, har været foretaget sådanne steder (Tanggaard, 2006a, b), men det er naturligvis vigtigt at påpege, at der også findes praktik fx i form af skolepraktik, som altså ikke finder sted på en virksomhed, men som baserer sig på nogenlunde de sammen principper om at lære gennem produktion, som vi kender det fra en virksomhedsbaseret praktik. Skolepraktik kan dog nærme sig skolen på den måde, at der ikke altid er den samme grad af autenticitet, som der vil være i en praktik på en virksomhed., fordi der i en vis grad er tale om en "kunstig" produktion, måske med rigtige kunder, men stadig designet specifikt med henblik på elevernes læreprocesser. Erhvervsuddannelserne er organiseret forskellige i forskellige lande, men i Danmark, som udgør den empiriske kontekst for artiklen her, finder det meste praktik sted som virksomhedspraktik, mens der er fx Norge vil være mere skolepraktik.

Læreprocesser og evaluering: Studier af læreprocesser forbundet til evaluering viser, at jo mere komplekse læreprocesser, vi ønsker at fremme, jo flere evalueringsstrenge har vi brug for (Beckman \& Barry, 2007). For en tømrerelev er det eksempelvis ikke nok, at vi tester om vedkommende har lært at beregne vinklen 
i et spær. Eleven skal også ofte være i stand til at arbejde i tværfaglige teams på byggepladsen, kommunikere med kunder og at kunne evaluere egne arbejdsprocesser og om nødvendigt ændre disse i takt med opgaverne. Det interessante er, hvordan man lærer elever at mestre denne samarbejdsorienterede, fleksible og kreative praksis. De fleste måder at teste elever på i skolen anvender ofte udprægede, individualiserede og dekontekstualiserede evalueringsformer, der hænger sammen med en individualiseret opfattelse af læring (Cole, 1996). Her opfattes læring at resultere i individuel tilvækst af viden, kunnen og færdigheder. I virkelighedens verden er det dog sjældent tilstrækkeligt at kunne noget alene. Her viser vores kompetencer sig ofte at være kontekstafhængige. Vi er afhængige af gode kollegaer, adgang til udfordrende og meningsfulde opgaver og en progression i disse i sværhedsgrad, hvis vi vil lære mere, og så bliver det straks sværere at lave præcise evalueringer af elevernes læreprocesser. Vi kan stadig godt måle på enkeltindividernes kompetencer, men denne måling svarer ikke særlig godt til de opgaver, der rent faktisk løses, hvor det måske er samarbejdet, som er det afgørende.

Formative, dynamiske former for evaluering: Af hensyn til fremme af læreprocesser kan vi have brug for at kunne gå fra rent summative, opsamlende og retrospektive evalueringer til mere formative evalueringer, der udvikler kompetencer samtidig med, at disse evaluereres. Her er der brug for dynamiske former for evaluering, der peger fremad i tid og som kan hjælpe eleven til at udvikle de kompetencer, evalueringen viser, der kan være brug for at fremme. Vi har derfor brug for evalueringer på erhvervsuddannelserne, der er "fit for purpose" (Brown, 2004), og som måler og former det, vi gerne vil måle og fremme. Vi bruger ofte essays, mundtlige prøver og multiple-choice, men hvad med port-folio, rollespil, posters og kundeevalueringer? Vi skal samtidig gøre det klart, hvorfor vi evaluerer? Vil vi kontrollere, teste, give feedback, motivere eller selektere? Jo større klarhed over formålet, jo større chance for at fremme de former for læring, vi intenderer at fremme.

Det er således tydeligt, at evaluering på ingen måde er et neutralt redskab. Som understreget af Moss, Pullin, Paul Gee og Haertel (2005, p. 77), så vil evaluering også forme sin egen genstand, hvorfor evaluering og læreprocesser altid vil stå i forbindelse med hinanden: "Testing shapes people's actions and understandings about what counts as trustworthy evidence, as learning or educational progress, as fairness or social justice, and as appropriate aims for an educational system". I psykologien er der en lang tradition for at understrege den dynamiske sammenhæng mellem netop evaluering og læreprocesser, noget der går helt tilbage til Lev Vygotskys oprindelige tænkning (Cole, 1996; van der Veer \& Valsiner, 1991), og som reflekteres i nye bestræbelser på at formulere, udvikle og anvende "dynamic assessment" (se Haywood \& Lidz, 2006; Lidz, 1987; Tzuriel, 2001) og "formative interventions" (Engeström, 2011). I sin essens angår dynamisk evaluering en bestræbelse på at tilpasse opgaverne til de niveauer, eleven 
er på og denne form for evaluering kan fint pågå i forskellige former for samarbejde og allerede eksisterende arbejde i læringsmiljøet eller klasseværelset. Dermed kan evaluering også anvendes som en mulighed for at fremme en bestemt udvikling hos eleven eller i hele gruppen/klassen (Black, Harrison, Lee, Marshall \& Wiliam, 2002; Shepard, 2000). I det følgende vil jeg kort beskrive 5A-modellen, der i denne sammenhæng danner grundlag for en model for dynamisk evaluering på erhvervsuddannelserne.

\section{A-modellen}

5A-modellen er oprindeligt udviklet af Glăveanu (2013) med den intention at udvikle en ny forståelse af kreativitet, der tager dennes kontekstafhængighed alvorligt. De fem elementer er som følger på engelsk: Actors, Audiences, Artefacts, Actions, and Affordances (5A). Det betyder i den oprindelige model, at kreativitet, der er omdrejningspunktet for Glăveanus forskning, ikke længere ses som noget, der er indlejret $\mathrm{i}$ individet. Kreativitet ses derimod snarere som en emergent form for handling, der igangsættes af en række aktører i relation til mange slags publikum og ved at udnytte redskaber og muligheder i omgivelserne for at kunne skabe noget nyt og værdifuldt for aktørerne selv eller for omgivelserne. Pointen med at inddrage de 5 A-dimensioner i denne sammenhæng er at bruge modellen som et dynamisk redskab til at tænke evaluering og læreprocesser sammen på en måde, således at evalueringen ikke alene bliver centrereret om elevens læreprocesser, men om hele læringskonteksten, en kontekst der inkluderer elever, lærere, mestre, svende, andre lærlinge, kunder og hele den institutionelle og kulturelle arena knyttet til forestillinger om, hvad man skal kunne som erhvervsuddannelseselev. Modellen er således ikke i første omgang udviklet med evaluering for øje, men de fem dimensioner kan netop pege på en meget kontekstafhængig og bredspektret tilgang til evaluering.

I det følgende vil jeg kort opridse en række aspekter og centrale evalueringsspørgsmål knyttet til de fem dimensioner, og herefter vil jeg diskutere og perspektivere modellen. Opdelingen mellem de fem dimensioner i modellen er naturligvis alene en analytisk skelnen, så spørgsmålene vil i praksis overlappe hinanden.

\section{Evaluering i praksis med afsæt i 5A-modellen}

Aktører: For at sikre progression i læreprocesser er det fordelagtigt at koncentrere evalueringen omkring den, der skal lære. Lave og Wenger (1991) skriver med afsæt i undersøgelser af lærlinges læreprocesser, at læring er en integreret del af deltagernes forandrede deltagelse i foranderlige praksisser. På erhvervsuddannelserne gælder dette for så vidt både på skole og i praktik. En evaluering af læring kan derfor med fordel fokusere på, hvordan lærlingens eller elevens 
deltagelse forandres, hvilken bevægelse og hvilken progression, der kan iagttages. Ofte evaluerer vi ved at sammenligne elever i henhold til en given standard eller skala, men i ovennævnte optik er det mindre interessant, hvor den enkelte elev ligger i sammenligning med andre elever. Det mest interessante er, hvordan den enkelte elev har flyttet sig i sin egen praksis. Herunder hvordan man om muligt kan bidrage til, at vedkommende flytter sig yderligere. Det er også helt relevant at undersøge elevens egen-vurdering og at lave egne læringsplaner. Hovedperspektivet med afsæt i 5A-modellen er, at aktørerne ses som ansvarlige, som netop aktører og som relationelt forbundet til andre aktører og til situationer og sociale praksisser, der giver bestemte muligheder for handling. I min egen forskning har jeg i den sammenhæng interesseret mig for kønnede læreprocesser. Det viste sig gennem kvalitative interviewstudier på henholdsvis mejeri- og elektronikområdet, at eleverne på erhvervsuddannelserne i Danmark oplevede forskelle i handlemuligheder relateret til deres køn. Kvinderne oplevede, at de indimellem skulle håndtere bemærkninger om egen krop, blandt andet på grund af gennemsigtige uniformer, og at de i perioder blev forholdt læringsmuligheder. De fik ikke sagt til eller fra på samme måde som mændene, der kunne fortælle om ofte at få et stort og selvstændigt ansvar, selvom de kun var lærlinge. De kastede sig mere ud i læringsmuligheder, fordi de fik mere og større adgang til dette (Tanggaard, 2006b). Eleverne oplevede selv, at mændene blev vurderet til at være mere kapable til at tage ansvar, mens dette ikke nødvendigvis altid var tilfældet. Tilskrivningen af evnen til at tage ansvar påvirkede dog oplæringens sociale praksis, således at kvinderne fik sværere ved at tage ansvaret. I et normativt evalueringsperspektiv er pointen, at det at opfatte sig selv som aktør i relation til evaluering i sig selv kan bidrage til at fremme læring, så jo mere, man på erhvervsskolerne kan få eleverne delagtiggjort i egen-vurderingen og få dem til at tage ansvar for at opsøge evaluering og feedback, jo bedre. Boud (2003) har i sit arbejde omkring selv-evaluering understreget, at denne form for evaluering bør stille en større rolle i uddannelsessystemet fremadrettet, da de fleste elever vil skulle forholde sig til krav om livslang læring og derfor vil få brug for at kunne guide og styre egne læreprocesser. Desuden er det sandsynligt, at det bliver sværere at opstille standarder for faglig kompetence i givne felter i længere tidsrum, så evnen til at kunne korrigere egne handlinger, at tilpasse sig og at påvirke nye standarder bliver ganske afgørende.

Action: Her er fokus på evaluering med afsæt i et handlingsperspektiv. Centrale spørgsmål er her, hvordan egne og andres handlinger kan bidrage til øget læring, og hvad der måtte forhindre dette? I relation til dette perspektiv på handlinger vil man i en evalueringsoptik lede efter tegn på læring ved at undersøge handlingsmønstre over tid, og ved at undersøge hvordan læring viser sig i form af ændret deltagelse og ændret praksis? Med afsæt i handlingsdimensionen kan man med fordel undersøge, hvordan bestemte handlinger fremadrettet vil kunne bidrage til mere læring, og hvordan hidtidige handlinger i et mere summativt 
perspektiv har resulteret $\mathrm{i}$ bestemte former for læring. I en evalueringsoptik er det centralt, at man spørger ind til de handlinger, der kan repræsentere ressourcer og barrierer for elevernes videre læring. Jo mere sagligt, man kan forbinde en evaluering og feedback til bestemte handlinger, jo nemmere kan det være for eleven at vide, hvilke indsatser, der for hendes vedkommende vil kunne fremme læring. Dette kobler sig fint til Falchikov og Bouds (2007) overvejelser over evaluering i et livslangt perspektiv, hvor et nærværende spørgsmål for undervisere og evalueringsdesignere er, hvordan man kan tænke evaluering, således at det har effekt på sigt. Hvorledes kan man således arbejde med evaluering, der gavner elevernes livslange udvikling, og hvordan kan eleverne selv tage ejerskab til evaluering ved at forholde sig til selvevaluering. Forfatterne nævner, hvordan det undervejs i Bouds eget uddannelsesforløb gik op for ham, at han kunne bruge flere ressourcer på at forholde sig og selv tage ansvar for at lære mere undervejs i sit uddannelsesforløb. Evaluering i et handlingsperspektiv drejer sig netop om spørgsmålet om ansvar og eget ansvar for at forholde sig til evaluering og ikke blot overlade det til at være lærernes eller undervisernes eller systemets ansvar.

Affordances: Er et ganske særligt og med al sandsynlighed også et nyt begreb i en evalueringsoptik. Begrebet er inspireret af Gibson, der i sin essens beskriver, hvordan affordances refererer til det, omgivelserne inviterer os til at gøre: "the affordances of the environment are what it offers the animal, what it provides or furnishes, either for good or ill" (Gibson, 1986, p. 127). Det handler således om de handlemuligheder, der findes i omgivelserne og som man kan gøre brug af i en evalueringssammenhæng. Her er det eksempelvis muligt at diskutere, hvordan forskellige kontekster som skole og praktik kan give eleverne forskellige muligheder - hvordan disse så at sige inviterer til forskellige typer af handlinger. De elever, jeg har fulgt i forskellige forskningsprojekter på erhvervsuddannelserne gennem tiden, har ofte oplevet, at de i praktikken i højere grad har kunnet udfolde egne ressourcer i sammenligning med skolen (Tanggaard, 2006). Praktikken har inviteret dem til eksempelvis at bruge hænderne mere, at udvise praktisk fornuft og for mange af eleverne har det været en gave, der har løsnet dem fra nogle af de indlæringsvanskeligheder, de måtte have oplevet på skolen (Tanggaard \& Szulevicz, 2013). Denne pointe kobler også til de grundlæggende dimensioner i 5A-modellen, hvor pointen netop er at tænke relationelt og at vise, hvordan bestemte handlinger og subjekt-positioner bliver mulige i bestemte kontekster. Når en elev trænger til at lære mere, så kan det i dette perspektiv være en pointe, at vi spørger ind til, om vi i tilstrækkelig grad har inddraget de affordances, som kunne muliggøre øget handlingspotentiale fra elevens side.

Audiences: Er også et uvant begreb i evalueringssammenhænge, men er ikke desto mindre interessant at se nærmere på. Det slående i en erhvervsuddannelsessammenhæng er, at der i skole og i praktik netop er meget forskellige publikum, og at der dermed også kan være tale om forskellige evalueringskulturer. I et tidligere arbejde baseret på undersøgelser af evalueringspraksis på 
erhvervsuddannelserne konkluderede vi, med afsæt i undersøgelser af praktikken på erhvervsuddannelserne, at en væsentlig del af evalueringskulturen i et arbejdende praksisfællesskab i praktikken er konsekvensevaluering, som på den ene side virker effektivt i forhold til at undgå fejl, men hvis tone dog også kan være unødig hård. Svendeprøven som er en overvejende summativ evaluering er den mest tydelige og institutionaliserede form for praksisevaluering (Tanggaard \& Elmholdt, 2008). De formative typer af evaluering, som led i den almindelige produktionsproces, er modsat ikke udskilt som en opgave i sig selv, men regulerer lærlingens deltagelse i de forskellige praksisfællesskaber på virksomheden. Vi konkluderede, at disse evalueringsformer kunne synliggøres og udvikles yderligere i praktikken og på skolen. Det gjaldt således en påpegning af det produktive ved, at evalueringsprocessen bliver integreret i selve læreprocessen og fungerer som et led i en igangværende produktion. Den mere formaliserede evaluering på skolen stod ofte i kontrast til denne praksisevaluering, og det blev derfor meget tydeligt, at eleverne på erhvervsuddannelserne ofte skal forholde sig til meget forskellige publikum, når de bliver evalueret.

Artefacts: Når vi evaluerer med afsæt i artefact-begrebet vil vi undersøge, hvad fagets redskaber bidrager til i en evalueringskontekst. Helt konkret vil faglige standarder i et givet felt ofte afhænge af kendskab til og færdigheder i redskabsbrug, så alene af den grund er redskaber og evaluering i praksis tæet forbundne aspekter af en faglig praksis. Man kan også i et artefact-perspektiv mere overordnet undersøge betydningen af redskaber for udviklingen af læreprocesser. Vil bestemte former for undervisningsteknologier eksempelvis fremme eller hæmme læring? Betyder det eksempelvis noget for læring, om vi arbejder analogt eller digitalt? I relation til pointen fremhævet tidligere gående på, at evaluering aldrig er et neutralt redskab, men i selve sin form og fremgangsmåde altid vil påvirke det, der evalueres, så giver artefact-dimensionen netop mulighed for at kunne diskutere, hvad det betyder at måle på bestemte måder og ved hjælp af bestemte redskaber. Hvordan vil ændrede evalueringspraksisser eksempelvis kunne påvirke det, der læres?

Schwendimann, Cattaneo, Dehler Zuffrey, Gurtner, Bétrancourt og Dillenbourg (2015) skriver på interessant vis i relation til dette, at teknologisk medierede erfaringsrum kan bruges til at facilitere elevernes bevægelse på tværs af skole og praktik i en erhvervsuddannelsessammenhæng. Der er stor forskel på skole og praktik, og Schwendimann et al. har med deres artikel ingen ambition om at udligne enhver forskel på skole og praktik, men de påpeger, at man med nyere teknologi kan hjælpe elevernes grænsekrydsninger mellem skole og praktik. Eleverne kan fx bruge mobiltelefonen til at dokumentere læreprocesser i praktikken ved at tage billeder, og eleverne kan på forskellig vis dokumentere læreprocesser undervejs ved at svare på spørgsmål eller have adgang til læringsmateriale i praktikken. Teknologien kan bringe skolastiske spørgsmål ind i praktikken og være medierende led mellem skole og praktik. Eleverne kan 
De fem A'er: En evalueringsmodel for læreprocesser på erhvervsuddannelserne

simpelthen bruge elektroniske portfolios til at være i forbindelse med skolen, når de er i praktikken og omvendt. Fordelen er, at mange elever finder det let at bruge mobilen til på den måde at holde kontakt og i realiteten også tage ansvar for egne læreprocesser med det digitale rum som støtte. Der er således store muligheder for at tænke artefakter med aktivt ind i evalueringsdesign.

\section{Diskussion}

Pointen i det ovenstående har været at inddrage en model, der ellers normalt ikke forbindes til evaluering og læreprocesser, da den er udviklet som en model til analyse af kreativitet. Ikke desto mindre har det været pointen at inddrage en model, der gør det muligt at tænke bredspektret om evaluering og læreprocesser med særlig fokus på erhvervsuddannelserne. Det kan diskuteres, om modellen bibringer noget nyt til evalueringsfeltet? Det er måske især begreber som affordances, audience og artefacter, der repræsenterer nye perspektiver på evalueringspraksis. De gør det muligt at tænke publikum, omgivelsernes inviterende karakter og redskaberne ind i overvejelser over muligheder for evaluering. Især på erhvervsuddannelserne, hvor praktik fylder en del er det værd at overveje, om de klassiske diskussioner af evaluering kan udvides, så vi får et bredere blik på, hvad og hvordan, der med fordel kan evaluereres med henblik på læring. Udvikles muligheder for evaluering optimalt i relation til omgivelsernes muligheder for at løsne enkeltelever fra eventuelle indlæringsvanskeligheder og inddrages nye redskaber og teknologi, der kan give elever andre muligheder end de eksisterende. Samtidig kan 5A-modellen som et væsentligt bidrag bruges til at understrege, hvad aktører, herunder eleverne selv, kan gøre for at bidrage til evaluering, noget der med al sandsynlighed bliver mere afgørende fremadrettet i uddannelsessystemet. Overordnet set er pointen med modellen at tilbyde den, der skal foretage evalueringer et redskab, der giver mulighed for at udvide perspektivet på, hvad evaluering omhandler og hvilke dimensioner, der kan inddrages i evalueringspraksis.

\section{Konklusion}

I denne artikel har jeg, på basis af 5A-modellen, vist hvordan man kan evaluere læreprocesser blandt eleverne på erhvervsuddannelserne $i$ henhold til de fem dimensioner ( $\mathrm{A}^{\prime} \mathrm{er}$ ) i modellen. Det blev understreget, at der er to afgørende dimensioner i enhver form for evaluering. Dels at kunne sætte standarder, dels at kunne vurdere opnåelse af disse standarder og at kunne bidrage til læring på basis af evaluering. Det blev understreget i kapitlet, at evaluering ikke fungerer som et neutralt redskab, men vil påvirke de læreprocesser, der søges vurdereret og denne dimension indgår netop også i 5A-modellen, idet det understreges, at der er et relationelt og dynamisk forhold mellem modellens enkelte dimensioner. 
Modellen kan med fordel udvikles og forankres endnu mere i eksisterende forskningsprojekter med specifikt sigte på evaluering. Der er således på nuværende tidspunkt stadig mest talt om en heuristisk model, der kan udfoldes og diskuteres endnu mere specifikt og empirisk med afsæt i erhvervsuddannelserne end det er lykkes i denne sammenhæng.

\section{Om forfatteren}

Lene Tanggaard er cand.psych., Ph.d., Rektor på Designskolen i Kolding og Professor i Pædagogisk Psykologi ved Institut for Kommunikation og Psykologi, Aalborg Universitet. Hun forsker i læreprocesser i uddannelsessystemet med særlig vægt på erhvervsuddannelse, betydningen af evaluering for læring og kreative læreprocesser. 
De fem A'er: En evalueringsmodel for læreprocesser på erhvervsuddannelserne

\section{Referencer}

Aastrup Rømer, T. (2003). Læring og evaluering i nyere uddannelsesteori. Ph.d.-afhandling indleveret ved Institut for Læring. Ålborg: Ålborg Universitet.

Beckman, S.L. \& Barry, M. (2007). Innovation as a learning process: Embedding design thinking. California Management Review, 50(1), 25-56.

Black, P., Harrison, C., Lee, C., Marshall, B. \& Wiliam, D. (2002). Working inside the black box: Assessment for learning in the classroom. London: King's College London School of Education.

Boud, D. (2003). Enhancing learning through self-assessment. New York: Routledge/ Falmer.

Cole, M. (1996). Cultural psychology: A once and future discipline. Cambridge: Belknap Press.

Engeström, Y. (2011). From design experiments to formative interventions. Theory \& Psychology, 21(5), 598-628.

Gibson, J.J. (1986). The ecological approach to visual perception. Hillsdale, New Jersey: Lawrence Erlbaum Associates.

Glăveanu, V.P. (2013). Rewriting the language of creativity: The five A's framework. Review of General Psychology, 17(1), 69-81.

Haywood, H.C. \& Lidz, C.S. (2006). Dynamic assessment in practice: Clinical and educational applications: Cambridge: Cambridge University Press.

Boud, D. \& Falchikov, N. (2007). Introduction: Assessment for the longer term. I D. Boud \& N. Falchikov (Red.), Rethinking assessment for higher education: Learning for the longer term (s. 3-13). London: Routledge.

Foss Hansen, H. (2001). Evaluering: Teori og praksis i designprocessen. Nordiske Organisationsstudier, 3(3), 43-62.

Lidz, C.S. (Red.) (1987). Dynamic assessment: An interactional approach to evaluating learning potential. New York, NY, US: Guilford Press.

Moss, P.A., Pullin, D., Paul Gee, J. \& Haertel, E.H. (2005). The idea of testing: Psychometric and sociocultural perspectives. Measurement: Interdisciplinary Research \& Perspective, 3(2), 63-83.

Nielsen, K. (2003). Når eleverne selv skal sige det. I K. Nielsen \& S. Kvale (Red.), Praktikkens læringslandskab (s. 219-236). København: Akademisk Forlag.

Schwendimann, B.A., Cattaneo, A.A.P., Dehler Zuffrey, J., Gurtner, J.

-L., Bétrancourt, M. \& Dillenbourg, P. (2015). The 'Erfahrraum': A pedagogical model for designing educational technologies in dual vocational systems. Journal of Vocational Education and Training, 67(3), 367-396.

Shepard, L.A. (2000). The role of assessment in a learning culture. Educational Researcher, 29(7), 4-14.

Tanggaard, L. (2006a). Læring og identitet. Aalborg: Aalborg Universitetsforlag.

Tanggaard, L. (2006b). Situating gendered learning in the workplace. Journal of Workplace Learning, 18(4), 220-234. 
Tanggaard, L. \& Elmholdt, E. (2008). Assessment in Practice: An inspiration from apprenticeship. Scandinavian Journal of Educational Research, 52(1), 97-116.

Tanggaard, L. \& Szulevicz, T. (2013). Sociale læreprocesser som analytisk strategi. Psyke E Logos, 34(1), 69-82.

Tanggaard, L. \& Glăveanu, V.P. (2014). Creativity assessment as intervention: The case-study of creative learning. Akademisk kvarter / Academic Quarter, 9, 1830.

Tzuriel, D. (2001). Dynamic assessment of young children. I D. Tzuriel, Dynamic assessment of young children (s. 63-75). Boston, MA: Springer.

Van der Veer, R. \& Valsiner, J. (1991). Understanding Vygotsky: A quest for synthesis. Oxford: Basil Blackwell. 